\begin{tabular}{|c|c|c|c|c|c|c|}
\hline \multirow{4}{*}{ Impact Factor: } & ISRA (India) & $=3.117$ & SIS (USA) & $=0.912$ & ICV (Poland) & $=6.630$ \\
\hline & ISI (Dubai, UAE & $=0.829$ & РИНЦ (Russia & $=0.156$ & PIF (India) & $=1.940$ \\
\hline & GIF (Australia) & $=0.564$ & ESJI (KZ) & $=8.716$ & IBI (India) & $=4.260$ \\
\hline & JIF & $=1.500$ & SJIF (Morocco & $=5.667$ & OAJI (USA) & $=0.350$ \\
\hline
\end{tabular}

\section{SOI: $1.1 /$ TAS DOI: $10.15863 /$ TAS International Scientific Journal Theoretical \& Applied Science}

p-ISSN: 2308-4944 (print) e-ISSN: 2409-0085 (online)

Year: 2019 Issue: $05 \quad$ Volume: 73

Published: $30.05 .2019 \quad \underline{\text { http://T-Science.org }}$
QR - Issue

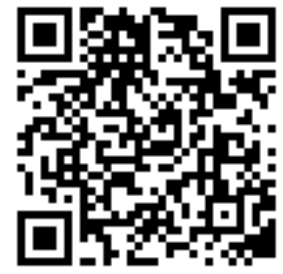

Maftuna Jo'rabekova

Student of KM-91 group, Economics Faculty Tashkent state university of economics, Tashkent city, Republic of Uzbekistan

Sadoqat Meyliyeva

Student of KM-91 group, Economics Faculty Tashkent state university of economics, Tashkent city Tashkent city, Republic of Uzbekistan

Abdumailk Abruyev

Student of MO-63 group, Corporate Governance Faculty Tashkent state university of economics, Tashkent city Tashkent city, Republic of Uzbekistan

Aziz Zikiryoev

Phd sudent, Departemnt of World Economy Tashkent state university of economics, Tashkent city Tashkent city, Republic of Uzbekistan

\title{
INVESTMENT ATTRACTIVENESS POLICY AS FOR THE PARALLEL GOAL OF STABLE ECONOMIC DEVELOPMENT IN UZBEKISTAN
}

Abstract: Foreign direct investment (FDI) in developing countries has a negative reputation. In some discussions, it is presented as tantamount to postcolonial exploitation of raw materials and cheap labor. However, recent data shows that FDI in developing countries increasingly flows to medium and high-skilled manufacturing sectors, involving elevated income levels. However to achieve investment attractiveness, host countries cannot just wait and see what international market forces may bring to them. Rather, they need tailored policies to overcome domestic imperfections that hinder the smooth integration of indigenous and foreign firms into world-wide supplychain networks.

Key words: Investment, economic growth, development policy, FDI, international cooperation, economic ranking.

Language: English

Citation: Jo'rabekova, M., Meyliyeva, S., Abruyev, A., \& Zikiryoev, A. (2019). Investment attractiveness policy as for the parallel goal of stable economic development in Uzbekistan. ISJ Theoretical \& Applied Science, 05 (73), 549-555.

Soi: http://s-o-i.org/1.1/TAS-05-73-85 Doi: crossef https://dx.doi.org/10.15863/TAS.2019.05.73.85

\section{INTRODUCTION}

As a result of large-scale reforms in Uzbekistan during the years of independence, the system of administrative and command-based governance has been abandoned, gradual market reforms have been implemented, and macroeconomic stability, high rates of the economy, maintaining inflation at the forecast level and facilitating the creation of favorable conditions for the development of small business and private entrepreneurship. Transition of Uzbekistan to a new socio-economic structure has caused many serious problems affecting the fundamental design of regional development planning. The sharp weakening of the state's role in coordinating the transition process to a market economy without historical experience, institutional and legal conditions and its reliable place in the international division of labor initiated the emergence of artificial barriers and obstacles that most have not been overcome to date. From this point of view partnership of Uzbekistan in international Relations provide macroeconomic 


\begin{tabular}{|c|c|c|c|c|c|c|}
\hline \multirow{4}{*}{ Impact Factor: } & ISRA (India) & $=3.117$ & SIS (USA) & $=0.912$ & ICV (Poland) & $=6.630$ \\
\hline & ISI (Dubai, UAE & $=0.829$ & РИНЦ (Russia & $=0.156$ & PIF (India) & $=1.940$ \\
\hline & GIF (Australia) & $=0.564$ & ESJI (KZ) & $=8.716$ & IBI (India) & $=4.260$ \\
\hline & JIF & $=1.500$ & SJIF (Morocce & $=5.667$ & OAJI (USA) & $=0.350$ \\
\hline
\end{tabular}

stability and investment attractiveness within the country.

\section{URGENCY}

Main objectivity of the article is in-depth analysis of the country's path of development models under the current global market conditions, and the growing competition in the conditions of globalization in Uzbekistan. Creating a completely new approach and the enhancement of the principles for the development of our state directed to the stable economic growth in the country. In order to further improve the effectiveness of the ongoing reforms, create conditions for the comprehensive and dynamic development of the state and society, modernize the country and liberalize all spheres of life, address the pressing issues of concern to the population and entrepreneurs. In the five priority areas of the Republic of Uzbekistan's development in 2017-2021, which was developed as a result of public law discussion, analysis of existing legislation, law enforcement practices and advanced international experience.

Currently many Programs for the Development of the Regions of the countries are directly tied to hidden reserves, which is generally consistent with the goals and objectives of the development of the territories

\section{Uzbekistan: Country Operations Business Plan (2018-2020)}

The country partnership strategy (CPS), 20122016 of the Asian Development Bank (ADB) for Uzbekistan supported infrastructure development and access to finance. Consultations with the government confirmed that the strategic focus of the CPS remains valid. The proposed country operations business plan (COBP), 2018-2020 for Uzbekistan extends the validity of the CPS, and is consistent with recent government initiatives. This COBP fully supports the strategy and reflects updated development priorities of Uzbekistan. To this end, this COBP includes operational support for transport, energy, municipal services, health, and access to finance. Support for the key drivers of change-private sector development, regional cooperation, governance, knowledge management, gender equity, and climate change and the environment - is integrated into the operational assistance [1].

Central Asia Regional Economic Cooperation (CAREC) Program

The Central Asia Regional Economic Cooperation, or CAREC, Program is a partnership of 11 countries (Afghanistan, Azerbaijan, People's Republic of China, Georgia, Kazakhstan, Kyrgyz Republic, Mongolia, Pakistan, Tajikistan, Turkmenistan, and Uzbekistan), supported by 6 multilateral institutions, working together to promote development through cooperation, leading to accelerated growth and poverty reduction. The Program's long-term vision is Good Neighbors, Good Partners, and Good Prospects. There is unprecedented opportunity for CAREC countries to emerge as a center of trade and commerce, achieve higher levels of economic growth, and reduce poverty. CAREC helps Central Asia and its neighbors realize their significant potential by promoting regional cooperation in four priority areas: Transport; Trade Facilitation; Energy, and Trade Policy [2].

Uzbekistan intends to develop long-term regional development concepts

On 27 June, the State Committee for Investment of the Republic of Uzbekistan organized a training seminar for representatives of the territorial units of the committee with the participation of specialists from the National Project Management Agency (NPMA), the Center for Economic Research (CER), the Institute for Forecasting and Macroeconomic research (IFMR). The event was devoted to discussion and explanation of the methodology for drafting longterm regional development concepts, the press service of the State Committee for Investments of Uzbekistan [3].

International Cooperation and Development

For the building partnerships for change in developing countries Uzbekistan ties prospective partnership with Western World Countries. Moreover, EU-Uzbekistan relations date back to 1991, when the European Commission launched the Technical Aid to the Commonwealth of Independent States (TACIS). Since 2007, EU has been delivering increasing development support to Uzbekistan through the Development Cooperation Instrument (DCI). Starting with a $€ 29$ million multiannual program (2007-2010), and followed by a $€ 42$ million program (2011-2013), the most recent indicative program (2014-2020) amounts to $€ 168$ million. As such, the EU's latest DCI program (2014-2020) has earmarked $€ 168$ million in support to rural development in the following 4 subsectors:

1. diversification/productivity,

2. sustainable management of natural resources and ecosystems,

3. employment and income generation,

4. enhancement of socio-economic living standards of the most vulnerable groups in rural areas [4].

Over the past eight years, UNDP has focused its work within four main themes in line with its mandate and corporate strategic planning tools. The following represents some of the key findings in each of these areas:

Poverty reduction: At the national level, UNDP provided important support to the development of the Welfare Improvement Strategy (2008-2010) 


\begin{tabular}{|c|c|c|c|c|c|c|}
\hline \multirow{4}{*}{ Impact Factor: } & ISRA (India) & $=3.117$ & SIS (USA) & $=0.912$ & ICV (Poland) & $=6.630$ \\
\hline & ISI (Dubai, UAI & $=0.829$ & РИНЦ (Russia & $=0.156$ & PIF (India) & $=1.940$ \\
\hline & GIF (Australia) & $=0.564$ & ESJI (KZ) & $=8.716$ & IBI (India) & $=4.260$ \\
\hline & JIF & $=1.500$ & SJIF (Morocco & $=5.667$ & OAJI (USA) & $=0.350$ \\
\hline
\end{tabular}

Democratic governance: UNDP has supported public administration reform largely through capacity development and supporting the effective use of information and communication technologies (ICT).

Energy and the environment: UNDP has provided important support to national authorities in policy and strategy development, especially in relation to the issue of the Aral Sea [5].

In February 2017, the Government announced a broad market-oriented reform program that included five priority areas: improving public administration and state-building; ensuring the rule of law and judiciary reform; maintaining economic growth and liberalizing the economy; enhancing social safety nets; and ensuring security and implementing a constructive foreign policy. The program also reiterated the authorities' commitment to ensuring macroeconomic stability, and improving the business climate in the country. World Bank states Uzbekistan economic indicators as followings [6]:

Liberalization of financial sector is a greater independence for the Central Bank of Uzbekistan (CBU), an assessment of banking sector resilience, the implementation of financial recovery plans (SOEs), and plans to reinitiate the previously stalled World Trade Organization.

\section{ANALYTICAL PART}

This strategic model, along with all the spheres, sets out a number of challenges facing the development of the economy. These include macroeconomic stability, aimed at further development and liberalization of the economy and to maintain high economic growth rates, to increase competitiveness of the national economy, to modernize and accelerate agriculture development, to continue institutional and structural reforms to reduce government participation in the economy, strengthening of priority positions, stimulating the development of small business and private entrepreneurship, complex and balanced socioeconomic development of regions, cities and towns, active involvement of foreign investments into the national economy through the improvement of the investment climate was shown.

1. Open markets and allow for FDI inflows. Reduce restrictions on FDI. Provide open, transparent and dependable conditions for all kinds of firms, whether foreign or domestic, including: ease of doing business, access to imports, relatively flexible labor markets and protection of intellectual property rights.

2. Set up an Investment Promotion Agency (IPA). A successful IPA could target suitable foreign investors and could then become the link between them and the domestic economy. On the one side, it should act as a one-stop shop for the requirements investors demand from the host country. On the other side, it should act as a catalyst in the host's domestic economy, prompting it to provide top notch infrastructure and ready access to skilled workers, technicians, engineers and managers that may be required to attract such investors. Moreover, it should engage in after-investment care, acknowledging the demonstration effects from satisfied investors, the potential for reinvestments, and the potential for cluster-development because of follow-up investments.

3. Put up the infrastructure required for a quality investor: such as sufficient close-by transport facilities (airport, ports), adequate and reliable supply of energy, provision of an adequately skilled workforce, facilities for the vocational training of specialized workers, ideally designed in cooperation with the investor.

4. Encourage spillovers from FDI into the indigenous economy. Local firms set up by managers who had started in multinational firms are more successful and more productive than others. Managers of local firms gain knowledge of new technologies and marketing techniques by studying and imitating their multinational competitors. Similarly, worker movements from multinational to local firms spread knowledge and skills.

5. Shape Export Processing Zones (EPZs) in a way that they spearhead into the domestic economy. Avoid EPZ regulations discriminating against the creation of local supplier relationships. Set up a secondary industrial zone for local suppliers, be it as a geographical site adjacent to formal export processing zones, or be it as a legal status allowing for easy foreign-domestic linkages with, for example, databanks and "marriage counselors", to assist in supplier selection.

According to these ways of attracting investment Uzbekistan also restarted to build economically strong position in sphere Investment. 


\begin{tabular}{llllll} 
& ISRA (India) $=3.117$ & SIS (USA) & $=\mathbf{0 . 9 1 2}$ & ICV (Poland) & $=\mathbf{6 . 6 3 0}$ \\
Impact Factor: & ISI (Dubai, UAE) $=\mathbf{0 . 8 2 9}$ & PVHL (Russia) $=\mathbf{0 . 1 5 6}$ & PIF (India) & $=\mathbf{1 . 9 4 0}$ \\
& GIF (Australia) $=\mathbf{0 . 5 6 4}$ & ESJI (KZ) & $=\mathbf{8 . 7 1 6}$ & IBI (India) & $=\mathbf{4 . 2 6 0}$ \\
JIF & $=\mathbf{1 . 5 0 0}$ & SJIF (Morocco) & $\mathbf{5 . 6 6 7}$ & OAJI (USA) & $\mathbf{0 . 3 5 0}$ \\
\hline
\end{tabular}

\begin{tabular}{|l|c|c|c|}
\hline & & Eastern \\
Europe \& & United States \\
Central Asia & Gzbekistan & 7.0 & 7.0 \\
\hline Index of Transaction Transparency* & 8.0 & 5.0 \\
\hline Index of Manager's Responsibility** & 3.0 & 5.0 \\
\hline Index of Shareholders' Power*** & 6.0 & 4.0 \\
\hline Index of Investor Protection**** & 6.0 & 6.0 \\
\hline
\end{tabular}

Figure 1. Country comparison for the protection of investors

Source: Source: Doing Business, 2019

Uzbekistan ranked 76th in the World Bank 2019

Doing Business, including a ranking as the 12th easiest country to start a business in. The country also ranks 158th out of 180 countries in Transparency International's Corruption Perceptions Index 2018. The Government's policy of establishing seven special economic zones with tax breaks for investors has made the country attractive to international capital. Examples include the Syrdaryo economic free zone and an October 2018 decree by Interim President Shavkat Miriyoey requesting "additional measures for the intensification and expansion of activities of free economic zones" (FDI Intelligence). Uzbekistan also sold up to USD 300 million in Eurobonds during 2018 to be used production and infrastructure projects (Bloomberg). Russia has approached Saudi Arabia and Uzbekistan to construct a nuclear plant in these countries through Rosatom, Russia's nuclear corporation (TASS). USD 2.7 billion in money transfers from Russia to Uzbekistan was reported by the Russian central bank in 2017. (Reuters). Restructuring of large state enterprises and joining the WTO would bolster Uzbekistan's plea for FDI, but the country has been slow to advance on said fronts (Reuters)[7].

\begin{tabular}{|c|c|c|c|}
\hline Foreign Direct Investment & 2015 & 2016 & 2017 \\
\hline FDI Inward Flow (million USD) & 66 & 133 & 96 \\
\hline FDI Stock (million USD) & 9,023 & 9,156 & 9,252 \\
\hline Number of Greenfield Investments*** & 18 & 23 & 10 \\
\hline FDI Inwards (in \% of GFCF $F^{* * *}$ ) & 0.3 & 0.3 & $\mathrm{n} / \mathrm{a}$ \\
\hline FDI Stock (in \% of GDP) & 13.6 & 13.5 & $\mathrm{n} / \mathrm{a}$ \\
\hline
\end{tabular}

Figure 2. Total FDI in Uzbekistan

Source: UNCTAD, 2019

To improve the business environment, the Government of Uzbekistan introduced in 2017 a number of legislative changes, including the cancellation of unscheduled, and seemingly arbitrary or punitive, inspections of businesses as of January 1, 2017; elimination of the requirement to convert certain percentages of hard currency export earnings at the official (artificially low) exchange rate; simplification of business registration procedures; creation of a Business Ombudsman office; and a Law on Countering Corruption that attempts to increase transparency in Government of Uzbekistan functions[8].

In 2017 in the regional structure of investments in fixed capital 60.5 percent of their total were used in
Tashkent, Bukhara, Kashkadarya and Tashkent regions. The following major investment projects were implemented in these regions: construction of a gas processing plant complex and development of the Kandym group of deposits, development and production of hydrocarbon in the Gissar investment block and the Ustyurt region, production of synthetic liquid fuel based on purified methane from the Shurtan MCC, construction of three blocks for gas desulfurization, development of the Yoshlik1 field and others. Uzbekistan carried out foreign trade operations with 175 countries around the world and reached a positive balance with 86 countries.

According to Uzbek legislation, the State must guarantee and protect the rights of foreign investors in 


\begin{tabular}{|c|c|c|c|c|c|c|}
\hline \multirow{4}{*}{ Impact Factor: } & ISRA (India) & $=3.117$ & SIS (USA) & $=0.912$ & ICV (Poland) & $=6.630$ \\
\hline & ISI (Dubai, UAI & $=0.829$ & РИНЦ (Russia & $=0.156$ & PIF (India) & $=1.940$ \\
\hline & GIF (Australia) & $=0.564$ & ESJI (KZ) & $=8.716$ & IBI (India) & $=4.260$ \\
\hline & JIF & $=1.500$ & SJIF (Morocco & $=5.667$ & OAJI (USA) & $=0.350$ \\
\hline
\end{tabular}

the country. Investment programs were launched in order to encourage big investments in the priority sectors. Programs include 86 foreign direct investment projects totaling 1.8 billion dollars, of which more than half is for the energy sector. Amongst the investors, China with the CNPC company, is expected to participate in the construction of a section of an oil pipeline. South Korea is involved in a chemical-gas complex and the Russian company Lukoil, in putting into operation gas wells.

Foreign specialists might assist in developing the investment market in Uzbekistan. During a meeting with a World Bank mission in Tashkent January 10, representatives of the Uzbekistani government asked the World Bank to co-operate in creating a venture capital ecosystem. The parties agreed to continue exchanging opinions on this issue [9].

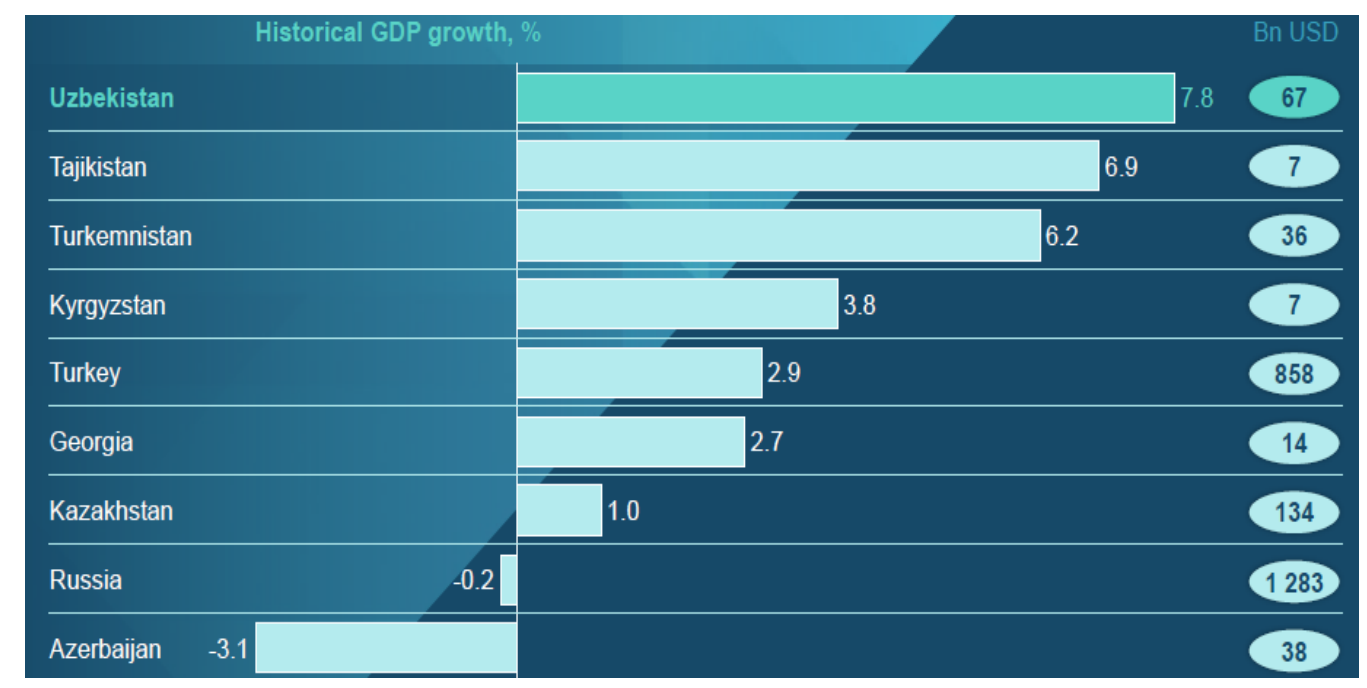

Figure 3. World's 5th fastest growing economy in 2015-16 - and expected to be in the TOP-3 by 2019 Source: This is the right time to invest in Uzbekistan, UZAFI 2018, and page 8.

Reforms in the modernization of production in our country require not only the modernization of technologies and technological processes used in enterprises, but also an innovative approach to management and accounting.

Uzbekistan's expanded engagement with foreign partners and international institutions contributes to improved relations with its Central Asian neighbors. Recent Uzbek initiatives have led to the construction of new transportation infrastructure, economic deregulation to simplify business entrepreneurship, liberalizing of national currency controls, and other market-oriented reforms in pursuit of Uzbekistan's goal of becoming a regional transportation and investment hub. These new tactics should help Uzbekistan better leverage its natural advantages, such as its pivotal geographic location. In particular, Uzbekistan is strategically positioned to benefit from China's infrastructure investment across Eurasia. Besides developing additional economic connections, the Uzbek government's new foreign policy approach could also generate social and economic opportunities for its citizens, strengthen the regional capacity to manage transnational threats, raise Uzbekistan's foreign economic profile beyond Central Asia, and help maintain geographic pluralism in the heart of Eurasia [10]. policy:

Innovation attractiveness of the economic

- stable foreign exchange rate;

- modernization of the economy;

- technology development;

- fdi promotion and investment climate;

- private property protection mechanisms;

- tax system;

- banking system and financial markets [11]. 


\begin{tabular}{|c|c|c|c|c|c|c|}
\hline \multirow{4}{*}{ Impact Factor: } & ISRA (India) & $=3.117$ & SIS (USA) & $=0.912$ & ICV (Poland) & $=6.630$ \\
\hline & ISI (Dubai, UAE & $=0.829$ & РИНЦ (Russia & $=0.156$ & PIF (India) & $=1.940$ \\
\hline & GIF (Australia) & $=0.564$ & ESJI (KZ) & $=8.716$ & IBI (India) & $=4.260$ \\
\hline & JIF & $=1.500$ & SJIF (Morocce & $=5.667$ & OAJI (USA) & $=0.350$ \\
\hline
\end{tabular}

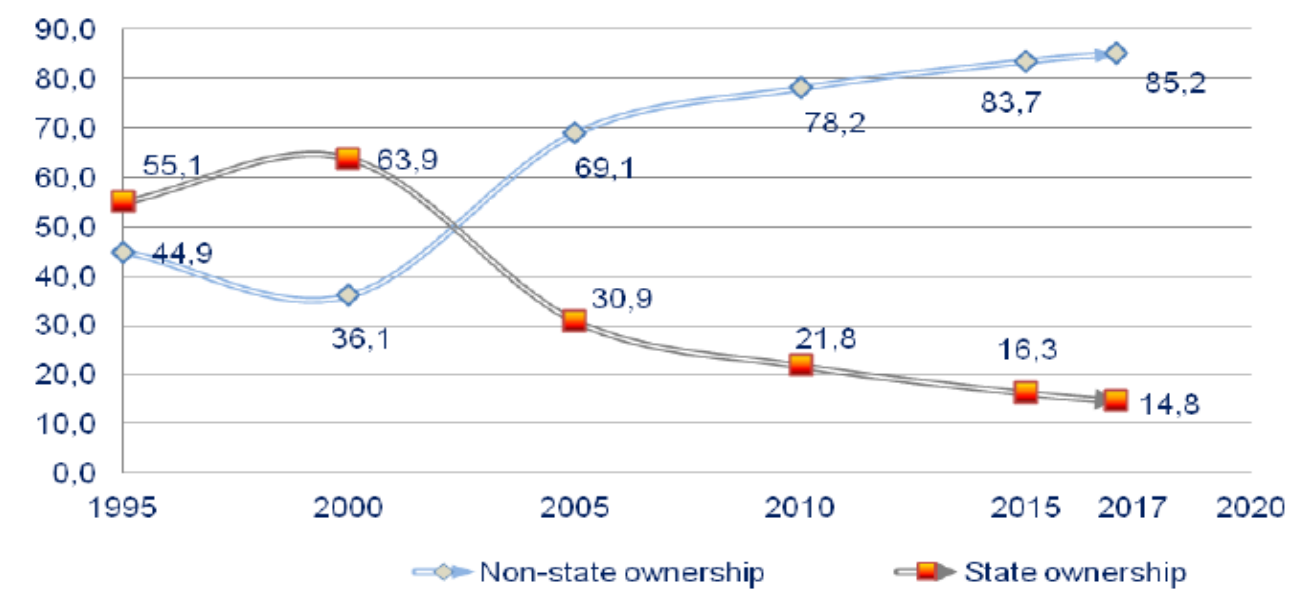

Figure 4. Infrastructure of Investment in Fixed Capital by ownership forms (percent) Source: Official data of Stat.uz

Most of the investments in fixed capital in 2017 were aimed at the construction of buildings and structures - 52.9 percent of the total investments. The share of investments in the development of the active part of fixed assets amounted to 41.0 percent against 38.3 percent in 2016, and increased by 2.7 percentage points (in comparison with 2005 by 1.0 percentage points, 2010 by 1.0 percentage points, 2015 by 1.2 percentage points respectively) [12].

\section{Liberalization of currency regulations:}

- exporters were required to sell $1 / 4$ of hard currency to the government;

- controlled exchange rate of the Uzbekistani Sum to the U.S. dollar;

- restricted amount of foreign currency individuals and companies could buy;

- exchange rate is determined by the free market.

Why Uzbekistan is an attractive investment destination?

- FDI attraction as a key priority for the country
- Economy liberalization and created a set of attractive incentives

- Uzbekistan improved by $90+$ points on World Bank Doing Business

- Political, economic, and investment environment is stable, predictable [13].

\section{CONCLUSION}

Taking into account under the conditions of economic changes in almost all fields of employment took place in all regions of the Uzbekistan. At the same time, there was a shortage of highly qualified specialists, high turnover was observed, natural aging of personnel, macroeconomic stability were noticeably felt as a shortage in many working professions under the International cooperation via various projects. Finally, Uzbekistan guarantees the right of foreign and domestic private entities to establish and own business enterprises and to engage in most forms of remunerative activity. Government supports all entities for long term cooperation with foreign investors with various attractive preferences. We hope modern investment policy helps maintain macroeconomic stability and financial development in the country

\section{References:}

1. (n.d.). Retrieved 2019, from https://www.adb.org/documents/uzbekistancountry-operations-business-plan-2018-2020
2. (n.d.). Retrieved 2019, from https://www.adb.org/countries/subregionalprograms/carec

3. (n.d.). Retrieved 2019, from https://www.daily.com/articles-id-44629.html 


\begin{tabular}{|c|c|c|c|c|c|c|}
\hline \multirow{4}{*}{ Impact Factor: } & ISRA (India) & $=3.117$ & SIS (USA) & $=0.912$ & ICV (Poland) & $=6.630$ \\
\hline & ISI (Dubai, UAE & $=0.829$ & РИНЦ (Russia & $=0.156$ & PIF (India) & $=1.940$ \\
\hline & GIF (Australia) & $=0.564$ & ESJI (KZ) & $=8.716$ & IBI (India) & $=4.260$ \\
\hline & JIF & $=1.500$ & SJIF (Morocce & $=5.667$ & OAJI (USA) & $=0.350$ \\
\hline
\end{tabular}

4. (n.d.). Retrieved 2019, from https://ec.europa.eu/europeaid/countries/uzbekis $\underline{\tan e n}$

6. (n.d.). Retrieved 2019, from https://www.oecd.org/countries/uzbekistan/468 $\underline{20458}$

7. (n.d.). Retrieved 2019, from http://www.worldbank.org/en/country/uzbekista n/overview

8. (n.d.). Retrieved 2019, from https://www.nordeatrade.com/en/explore-newmarket/uzbekistan/investment

9. (2018). Country profile Uzbekistan ,Uzbekistan: Investing in Uzbekistan, 2018 World Investment Report.
10. (n.d.). Retrieved 2019, from http://central.asianews.com/en_GB/articles/cnmi_ca/features/201 8/01/24/feature-01

11. (n.d.). Retrieved 2019, from http://isdp.eu/publication/uzbekistans-newforeign-policy/

12. (n.d.). Retrieved 2019, from https://www.wko.at/service/aussenwirtschaft/ro und-table-usbekistan-16.5.2018praesentationsfolien

13. (n.d.). Retrieved 2019, from https://stat.uz/uploads/docs/investitsiya-yandek-2017en2

14. (2018). This is the right time to invest in Uzbekistan, UZAFI, p.3. 